\title{
KONSEP DIAGNOSA KEPERAWATAN
}

\author{
Friderikus Zebua \\ zebuafriderikus@gmail.com
}

\section{LATAR BELAKANG}

Diagnosa keperawatan merupakan keputusan klinik tentang respon individu,keluarga dan masyarakat tentang masalah kesehatan paien baik yang aktual atau potensial yang didapatkan berdasarkan hasil pengkajian dan pemeriksaan keperawatan, Hal ini merupakan komponen dari langkah - langkah pemeberian asuhan keperawatan yang salah satunya adalah penetapan diagnosa keperawatan berdasarkan pendidikan dan pengalamannya, perawat secara akuntabilitas dapat mengidentifikasi dan memberikan intervensi secara pasti untuk menjaga, menurunkan,membatasi, mencegah dan merubah status kesehatan klien.

Diagnosa keperawatan memberikan dasar petunjuk untuk memberikan terapi yang pasti dimana perawat yang bertanggung jawab di dalamnya yang merupakan tahan selanjutnya pada proses keperawatan yang dilakukan setelah pengkajian.

Diagnosa keperawatan adalah pernyataan mengenai masalah kesehatan klien yang aktual atau potensial yang dapat dikelola melalui intervensi keperawatan mandiri. Diagnosa keperawatan adalah pernyataan yang ringkas, jelas, berpusat pada klien, dan spesifik pada klien. Diagnosa keperawatan adalah suatu pernyataan yang menjelaskan respons manusia (status kesehatan atau resiko perubahan pola) dari individu atau kelompok dimana perawat secara akuntabilitas dapat mengidentifikasi dan memberikan intervensi secara pasti untuk menjaga status kesehatan menurunkan, membatasi, mencegah, dan merubah (a Carpenito, 2000).

NANDA menyatakan bahwa diagnosa keperawatan adalah "keputusan klinik tentang respon individu, keluarga dan masyarakat tentang masalah kesehatan aktual atau potensial, sebagai dasar seleksi intervensi keperawatan untuk mencapai tujuan asuhan keperawatan sesuai dengan kewenangan perawat" Diagnosa keperawatan menjadi dasar untuk pemilihan tindakan keperawatan untuk mencapai hasil bagi.anda, sebagai perawat, yang dapat.diandalakan(NANDA Internasional,.2007) 
Diagnosa keperawatan berfokus pada, respon aktual atau potensial klien terhadap masalah kesehatan dibandingkan dengan kejadian fisiologis, komplikasi, atau penyakit. Pada beberapa area, perawat praktik atau vokasional tidak membuat diagnosa keperawatan: diagnosa keperawatan dianggap sebagai tugas RN. Ingat bahwa doagnosa keperawatan adalah label yang telah diakui yang mengidentifikasi masalah klien dalam terminologi keperawatan.

\section{METODE}

Kajian ini menggunakan literature review dari 10 referensi berdasarkan buku teks, buku referensi, jurnal e-book, Tesis, majalah dan koran (10 tahun terakhir) dengan menganalisis, eksplorasi, dan kajian bebas.

\section{HASIL}

Suatu diagnosis keperawatan tidak perlu berisi semua jenis indikator. Diagnosis keperawatan berfokus - masalah mengandung batasan karakteristik dan faktor yang berhubungan . diagnosis promosi kesehatan umumnya hanya batasan karakteristik, meskipun faktor yang berhubungan dapat digunakan jika dapat meningkatkan pemahaman diagnosis. Hanya diagnosis risiko yang memiliki faktor risiko.

Diagnosa keperawatan merupakan dasar dari penyusunan rencana tindakan asuhan keperawatan. Diagnosis keperawatan sejalan dengan diagnosis medis sebab dalam mengumpulkan data-data saat melakukan pengkajian keperawatan yang dibutuhkan untuk menegakkan diagnosa keperawatan ditinjau dari keadaan penyakit dalam diagnosa medis.

Contoh diagnose keperawatan dan prioritas masalah berdasarkan analisis.data.

1.hipertemia berhubungan dengan tekanan darah menurun, ditandai dengan gelisah, kulit tampak pucat,kulit kemerahan. ( Nanda hal 434)

2. insomnia berhubungan dengan gelisah ditandai dengan kesulitan memulai tidur,kesulitan mempertahankan tidur nyenyak, tidur tidak memuaskan (Nanda hal 211).

\section{PEMBAHASAN}

Suatu diagnosa keperawatan adalah penelitian klinis tentang respons manusia terhadap gangguan kesehatan atau proses kehidupan, atau kerentanan terhadap respons tersebut dari seorang individu, keluarga, kelompok, atau komunitas (NANDA-I 2013). Suatu diagnosa 
keperawatan biasanya berisi dua bagian yaitu, deskriptor atau pengubahan, dan fokus diagnos, atau konsep kunci dari diagnosa. Perawat mendiagnosis masalah kesehatan, menyatakan risiko, dan kesiapan promosi kesehatan. Diagnosis berfokus masalah tidak boleh dipandang lebih penting dari pada diagnosis risiko.

Kadang-kadang diagnosis risiko dapat menjadi diagnosis dengan prioritas tertinggi bagi pasien. Sebuah contoh mungkin pasien yang memiliki diagnosis keperawatan toleran aktivitas, hambatan memori, kesiapan meningkatkan manajemen kesehatan, risiko jatoh, dan baru di rawat di fasilitas perawatan. Setiap diagnosis keperawatan memiliki label dan defenisi yang lebih jelas.

Hal ini penting untuk menyatakan bahwa apakah label atau daftar label yang ada tidak mencukupi. Sangat penting bahwa perawat menegetahui defenisis diagnosis yang paling sering mereka gunakan. Selain itu, perawat perlu mengetahui "indikator diagnostik" data yang digunakan untuk mendiagnosi dan membedakan suatu diagnosis dari yang lain. Indikator diagnostik meliputi batasan karakteristik dan faktor yang berhubungan atau faktor risiko.

Dalam menentukan diagnosa diagnosa keperawatan ada beberapa hal yang harus diperhatikan meliputi (yustiana Olfah.2016) :

a. Tuliskan masalah/problem pasien atau perubahan status kesehatan pasien setelah dilakukan pengkajian .

b. Masalah yang dialami pasien didahului dengan adanya penyebab dan keduanya dihubungkan dengan kata "sehubungan dengan atau berhubungan dengan".

c. Setelah masalah (problem) dan penyebab (etiologi), kemudian diikuti dengan tanda dan gejala (symtom) yang dihubungkan dengan kata "ditandai dengan".

d. Tulis istilah atau kata-kata yang umum digunakan.

e. Gunakan bahasa yang tidak memvonis.

Langkah-Langkah Penulisan Diagnosa Keperawatan terdiri dari :

1. Pengelompokan Data dan Analisa data Setelah dilakukan pengkajian selanjutnya kita melakukan tahap analisis data untuk mempermudah penegakan diagnosis keperawatan meliputi : 
$>$ Data Subjektif, Data subjektif adalah data yang didapat dari hasil keluhan klien sendiri Contoh klien mengeluh gelisah dan tidak bisa tidur.

$>$ Data Objektif, Data subjektif adalah data yang didapat dari hasil pengkajian perawat sendiri contoh ; "TB $=165 \mathrm{~cm}, \mathrm{BB}=45 \mathrm{~kg}$ “.

$>$ Penyusunan Diagnosa Keperawatan (dengan rumusan $\mathrm{P}+\mathrm{E}+\mathrm{S}) \mathrm{P}=$ Problem/permasalah E = Etiologi/ penyebab penyakit $\mathrm{S}=$ Symptom / data subjektif dan data objectif. Contoh: Gangguan pemenuhan nutrisi : kurang dari kebutuhan tubuh berhubungan dengan intake yang tidak adekuat ditandai dengan klien mengatakan BB turun lebih dari $10 \mathrm{~kg}$ dalam 12 bulan terakhir, $\mathrm{TB}=165 \mathrm{~cm}, \mathrm{BB}=45 \mathrm{~kg}$. contoh : peningkatan suhu tubuh diatas nilai normal berhubungan dengan penurunan tekanan darah dan ditandai dengan pasien mengeluh gelisah Suhu 38 derjat Celsius ,tekanan darah rendah.

$>$ Dari contoh diagnosa di atas, dapat diketahui: Problemnya adalah: : peningkatan suhu tubuh diatas nilai normal, Etiologinyaadalah : penurunan tekanan darah Symtomnya adalah: gelisah. Suhu 38 derjat Celsius ,tekanan darah rendah. Contoh analisis data menggunakan table :

\begin{tabular}{|c|c|c|}
\hline Symptom & Etiologi & Problem \\
\hline$(\mathrm{s})$ & $(\mathrm{E})$ & $(\mathrm{p})$ \\
\hline
\end{tabular}

2. . Katagori Diagnosa Keperawatan Diagnosa keperawatan dapat dibedakan menjadi beberapa kategori:

> Aktual, Diagnosa Keperawatan aktualnmenjelaskan masalah nyata saat ini sesuai dengan data klinik yang ditemukan. Syarat menegakkan diagnosa keperawatan aktual harus ada unsur PES. Symptom (S) harus memenuhi kriteria.mayor dan sebagian kriteria minor dari.pedoman diagnosa NANDA. Misalnya:.Hasil pengkajian diperoleh data klien.mual, muntah, diare dan turgor jelek.selama 3 hari. Diagnosa: Kekurangan.volume cairan tubuh berhubungan dengan.kehilangan cairan secara abnormal.

$>\quad$ Risiko .Diagnosa Keperawatan Risiko.menjelaskan masalah kesehatan yang.nyata akan terjadi jika tidak dilakukanintervensi. Syarat menegakkan risiko.diagnosa keperawatan adanya unsur PE.(problem dan etiologi). Penggunaan.istilah "risiko dan risiko 
tinggi".tergantung dari tingkat.keparahan/kerentanan terhadap masalah CDiagnosa: "Risiko gangguan integritas.kulit berhubungan dengan diare yangterus menerus".

$>$ Kemungkinan Diagnosa Keperawatan Kemungkinan menjelaskan bahwa perlu adanya data.tambahan untuk memastikan masalah.keperawatan kemungkinan. Pada keadaan.ini masalah dan faktor pendukung belum ada tapi sudah ada faktor yang dapat.menimbulkan masalah.Syarat.menegakkan kemungkinan diagnosa.keperawatan adanya unsur respons.(Problem) dan faktor yang mungkin dapat.menimbulkan masalah tetapi belum ada..Contoh: Diagnosa: Kemungkinangangguan konsep diri: rendah diri/terisolasi berhubungan dengan diare. Perawat dituntut untuk berfikir lebih kritis dan mengumpulkan data tambahan yang berhubungan dengan konsep diri.

> Diagnosa Keperawatan "Wellness" Diagnosa keperawatan wellness (sejahtera) adalah keputusan klinik.tentang keadaan individu, keluarga, dan atau masyarakat dalam transisi dari tingkat sejahtera tertentu ke tingkat sejahtera yang lebih tinggi. Ada 2 kunci yang harus ada: 1) Sesuatu yang menyenangkan pada tingkat kesejahteraan yang lebih tinggi 2) Adanya status dan fungsi yang efektif.

\section{PENUTUP}

Diagnose keperawatan merupakan komponen dari langkah - langkah pemeberian asuhan keperawatan yang salah satunya adalah penetapan diagnosa keperawatan berdasarkan pendidikan dan pengalamannya, perawat secara akuntabilitas dapat mengidentifikasi dan memberikan intervensi secara pasti untuk menjaga, menurunkan,membatasi, mencegah dan merubah status kesehatan klien menjadi lebih baik.

Diagnosa keperawatan memberikan dasar petunjuk untuk memberikan terapi yang pasti dimana perawat yang bertanggung jawab di dalamnya yang merupakan tahap selanjutnya pada proses keperawatan yang dilakukan setelah pengkajian.

Diagnosis keperawatan ditetapkan berdasarkan analisis dan interpretasi data yang diperoleh dari pengkajian keperawatan klien Diagnosis keperawatan memberikan gambaran tentang masalah atau status kesehatan klien yang nyata (aktual) dan kemungkinan akan terjadi, dimana pemecahannya dapat dilakukan dalam batas wewenang perawat. 


\section{DAFTAR PUSTAKA}

Carrol. (2010). Memahami Proses Keperawatan.Jakarta : EGC.

Departemen Kesehatan RI. (2010). Standar Asuhan Keperawatan, Jakarta.

Dinarti dan Yuli. (2017). Dokumentasi Keperawatan.Jakarta.Kementrian kesehatan Republik Indonesia.

Kozier dkk. (2010). Fundamental Keperawatan KonsepEGC6roses, dan Praktik Edisi 7 Volume 2. Jakarta : EGC.

Kozier dkk. (2015). Buku Ajar Fundamental Keperawatan,Konsep,Proses,dan Praktik Volume 7. Jakarta : EGC.

NANDA International. (2005). Diagnosa Keperawatan Definisi dan Klasifikasi 2009-2011. Dialih bahasakan oleh Made Sumarwati. Jakarta : EGC

Simamora, R. H., Bukit, E., Purba, J. M., \& Siahaan, J. (2017). Penguatan kinerja perawat dalam pemberian asuhan keperawatan melalui pelatihan ronde keperawatan di rumah sakit royal prima medan. Jurnal pengabdian kepada masyarakat, 23(2), 300-304.

Simamora, R. H. (2019). Socialization of Information Technology Utilization and Knowledge of Information System Effectiveness at Hospital Nurses in Medan, North Sumatra. Editorial Preface From the Desk of Managing Editor..., 10(9).

Susanto. 2012. Buku Ajar Keperawatan Keluarga: Aplikasi Pada Praktik Asuhan Keperawatan Keluarga. jakarta: CV Trans info medika.

Tarwoto dan Wartonas. (2015). Kebutuhan Dasar Manusia dan Proses Keperawatan. Yogyakarta. Salemba medika.

Wahid, Abdul. (2012). Dokumentasi Proses Keperawatan. Yogyakarta,PT. Nuha Medika.

Yustiana \& Abdul. (2016). Dokumentasi keperawatan.jakarta.kementrian kesehatan Republik Indonesia. 